\title{
Rejestr instytucji pożyczkowych prawny instrument poprawy bezpieczeństwa na rynku pożyczek konsumenckich
}

\author{
Register of loan institutions - legal instrument \\ for safety improvement on the consumer loan market
}

\author{
prof. dr hab.Zbigniew Ofiarski
}

E-mail: zbigniew.ofiarski@usz.edu.pl; nr ORCID: 0000-0003-1675-933X

\begin{abstract}
Streszczenie
Wprowadzenie od 2017 r. obowiązku wpisu instytucji pożyczkowych do rejestru publicznego, prowadzonego przez Komisję Nadzoru Finansowego, jest kolejnym etapem prac legislacyjnych zmierzających do poprawy ogólnego poziomu bezpieczeństwa na pozabankowym rynku pożyczek pieniężnych udzielanych konsumentom. Wcześniejsze zmiany ustawodawstwa dokonane w 2015 r. polegały na sformułowaniu ustawowych warunków (organizacyjnych, kapitałowych i personalnych), których spełnienie uprawnia do prowadzenia działalności w charakterze instytucji pożyczkowej. W opracowaniu przeprowadzono szczegółową analizę regulacji prawnych warunkujących uzyskanie statusu instytucji pożyczkowej. Wykazano, że wpis do rejestru instytucji pożyczkowych ma charakter konstytutywny, ponieważ od niego uzależniono możliwość podjęcia działalności w zakresie udzielania pożyczek w sposób ciągły, zorganizowany i odpłatny, a więc mający znamiona działalności gospodarczej. Ponadto ustalono, że działalność instytucji pożyczkowych jest działalnością regulowaną w rozumieniu Prawa przedsiębiorców. Zidentyfikowano dwie podstawowe funkcje realizowane przez rejestr instytucji pożyczkowych, tzn. selektywną (wobec podmiotów ubiegających się o wpis do rejestru) oraz informacyjną (o podmiotach już ujętych w rejestrze). Ustalono istotę i charakter opłat pobieranych za dokonanie wpi- su do rejestru lub jego zmianę albo wykreślenie z rejestru. W konkluzji oceniono, że wprowadzenie obowiązkowego wpisu do rejestru umożliwiło pozytywne wyróżnienie instytucji pożyczkowych w ogólnej kategorii parabanków.
\end{abstract}

Słowa kluczowe: pożyczka, konsument, instytucja pożyczkowa, rejestr publiczny, bezpieczeństwo na rynku pożyczek

\section{Summary}

Introduced in 2017 obligation to register loan institutions in the public register kept by the Polish Financial Supervision Authority, shall be another stage of legislative works aimed at the improvement of the general safety level on the non- bank market of financial loans offered to consumers. Legislation changes introduced in 2015 consisted in the formation of legal conditions (organizational, capital and personal) to be met in order to be authorized to conduct activity as a loan institution. This work includes a detailed analysis of the regulatory policies conditioning receiving the loan institution status. It proves that the entry to the register of loan institutions is of constitutive nature, since it determines the ability to undertake activity in scope of granting loans in a continuous and paid way, thus with the features of economic activity. Additionally, it is determined that the loan institutions' activity is regulated within the meaning of the act - Prawo przedsiębiorców [Entrepreneurs' Act]. Two basic functions of the register of loan institutions are identified, i.e. selective function (in relation to the entities applying for the entry to the register) and informative function (about the entities included in the register). The essence and nature of the fees collected for the entry to the register or for a change or deletion from the register have been determined. The conclusion states that introduction of the compulsory entry to the register enables positive identification of loan institutions among the general category of near banks.

Key words: loan, consumer, loan institution, public register, safety on loan market

JEL: G21, G 23

Str. 2-9 


\section{Bibliografia}

Bernat, M. (2018). Analiza regulacji prawnych dotyczących sektora parabankowego — firm pożyczkowych. W: I. JakubowskaBranicka (red.), Rynek firm pożyczkowych w Polsce. Teoria i praktyka (57-94). Warszawa: Polskie Towarzystwo Ekonomiczne.

Czech, T. (2018). Kredyt konsumencki. Komentarz. Warszawa: Wolters Kluwer.

Domańska-Szaruga, B. (2015). Rynek firm pożyczkowych w Polsce i propozycje jego uregulowania. W: J. Ostaszewski (red.), O nowy ład finansowy w Polsce. Rekomendacje dla animatorów życia gospodarczego (19-31). Warszawa: Wydawnictwo Szkoły Głównej Handlowej.

Etel, M. (2017). Kontrola i odpowiedzialność jako problemy charakteryzujące regulowaną działalność gospodarczą (analiza z uwzględnieniem działalności telekomunikacyjnej). Prace Naukowe Uniwersytetu Ekonomicznego we Wrocławiu, (495), 18-32.

Grochowski M. (2018). Komentarz do art. 59aa. W: K. Osajda (red.), Ustawa o kredycie konsumenckim. Komentarz. Legalis: C.H. Beck.

Herman, A. (2018). Struktura i dynamika pozabankowego sektora pożyczkowego w Polsce. W: I. Jakubowska-Branicka (red.), Rynek firm pożyczkowych w Polsce. Teoria i praktyka (95-142). Warszawa: Polskie Towarzystwo Ekonomiczne.

Konfederacja Przedsiębiorstw Finansowych w Polsce. (2018). Wyzwania dla instytucji pożyczkowych w roku 2018. https://kpf.pl (28.03.2019)

Księżopolski, R. (2012). Finansowanie potrzeb konsumenckich przez parabanki w Polsce. W: G. Kotliński, K. Waliszewski (red.), Instytucje parabankowe na rynku ustug bankowych w Polsce (113-130). Warszawa: Wydawnictwo CeDeWu.

Malarewicz-Jakubów, A. (2018). Komentarz do art. 43. W: G. Kozieł (red.), Prawo przedsiębiorców. Przepisy wprowadzające do Konstytucji Bizne- su. Komentarz (255-262). Warszawa: C.H. Beck.

Markowski, K., Tymoczko, D. (red.). (2015). Rozwój systemu finansowego w Polsce w 2014 r. Warszawa: Narodowy Bank Polski.

Tomkowicz, R. (2018). Sektor firm pożyczkowych w Polsce po pierwszej połowie 2018 r., Raport cykliczny Konferencji Przedsiębiorstw Finansowych $w$ Polsce. https://kpf.pl (5.12.2018).

Waliszewski, K. (2012). Miejsce i rola parabanków w systemie finansowym i gospodarce. W: G. Kotliński, K. Waliszewski (red.), Instytucje parabankowe na rynku ustug bankowych w Polsce (53-76). Warszawa: Wydawnictwo CeDeWu.

\section{Akty prawne}

Ustawa z 23.04.1964 r. — Kodeks cywilny (Dz.U. z 2018 r. poz. 1025 ze zm.).

Ustawa z 15.02.1992 r. o podatku dochodowym od osób prawnych (Dz.U. z 2019 r. poz. 865 ze zm.).

Ustawa z 29.08.1997 r. — Prawo bankowe (Dz.U. z 2018 r. poz. 2187 ze zm.).

Ustawa z 27.07.2002 r. - Prawo dewizowe (Dz.U. z 2019 r. poz. 160 ze zm.).

Ustawa z 5.11.2009 r. o spółdzielczych kasach oszczędnościowo-kredytowych (Dz.U. z 2018 r. poz. 2386 ze zm.).

Ustawa z 12.05.2011 r. o kredycie konsumenckim (Dz.U. z 2018 r. poz. 993 ze zm.).

Ustawa z 5.08.2015 r. o rozpatrywaniu reklamacji przez podmioty rynku finansowego i o Rzeczniku Finansowym (Dz.U. z 2018 r. poz. 1038 ze zm.).

Ustawa z 5.08.2015 r. o zmianie ustawy o nadzorze nad rynkiem finansowym oraz niektórych innych ustaw (Dz.U. poz. 1357).

Ustawa z 15.01.2016 r. o podatku od niektórych instytucji finansowych (Dz.U. z 2017 r. poz. 1410 ze zm.).

Ustawa z 1.03.2018 r. o przeciwdziałaniu praniu pieniędzy oraz finansowaniu terroryzmu (Dz.U. poz. 723 ze zm.).

Ustawa z 6.03.2018 r. - Prawo przedsiębiorców (Dz.U. poz. 646 ze zm.).

Ustawa z 12.04.2018 r. o zasadach pozyskiwania informacji o niekaralności osób ubiegających się o zatrudnienie i osób zatrudnionych w podmiotach sektora finansowego (Dz.U. z 2018 r. poz. 1130). 